\title{
Recurrent haematuria and mesangial IgA deposition
}

\author{
D. R. DAVIES, J. R. TIGHE, N. F. JONES, AND G. W. BROWN \\ From the Department of Surgical Pathology and Renal Unit, St Thomas' Hospital, London
}

SYNOPSIS Six patients are described in whom recurrent haematuria was associated with $\operatorname{IgA}$ deposits in the glomerular mesangium. These patients conform closely to the nephropathy described by Berger. The condition can only be definitely diagnosed by immunofluorescence techniques. These six patients were diagnosed in one renal unit within 18 months and, despite the absence of reports from British units, this nephropathy is probably not uncommon. No treatment for it if known at present but the prognosis appears to be good in most patients. Renal failure and hyperos tension have been reported and long-term follow up is necessary to clarify the natural history off the disease.

Recurrent or persistent haematuria occurs in some patients without any clinically demonstrable lesion in the urinary tracts, with normal renal radiology, and with normal haemostasis. The results of renal biopsy in several hundred such patients have been published and in the larger series the incidence of glomerular lesions found has varied considerably (Bodian, Black, Kobayashi, Lake, and Schuler, 1965; Lannigan and Insley, 1965; Arneil, Lam, McDonald, and McDonald, 1969; Burkholder, Dotin, Thomason, and Beach, 1969; Glasgow, Moncrieff, and White, 1970; Hendler, Kashgarian, and Hayslett, 1972; Chen, Ooi, Tan, and Khoo, 1972). The proportion of patients without glomerular abnormalities on light microscopy varied in these surveys from 0 to $45 \%$. The abnormalities most often described are focal or generalized proliferative glomerulonephritis.

Recently Berger and others in France have described a nephropathy in which the clinical presentation of haematuria is associated with the deposition in the glomerular mesangium of $\operatorname{IgA}$,

Received for publication 29 June 1973. usually accompanied by complement and Ig $\frac{\mathbb{D}}{\Phi^{+}}$ (Berger, Neveu, Morel-Maroger, and Antoine 1967; Berger and Hinglais, 1968; Berger, 1969 Druet, Bariety, Bernard, and Lagrue, 1970; Bariety

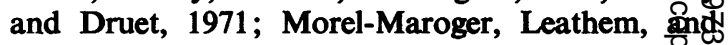
Richet, 1972). We have seen six patients with this syndrome within the past 18 months. This resion describes these patients and the appearances of the renal biopsies by light microscopy and electro microscopy, together with the results of immunof fluorescence studies.

\section{Clinical Features and Investigations}

These are summarized in tables I and II. The six. patients were all young adults with a history intermittent haematuria for four to 12 months before referral. In three patients episodes of macro. scopic haematuria usually followed upper respirator infections, and in two it was produced by exercis With one exception, microscopic haematuria peo sisted between the episodes and was accompanied by proteinuria. There was loin pain in two patients. The initial episode of haematuria was accompanied b⿸广स

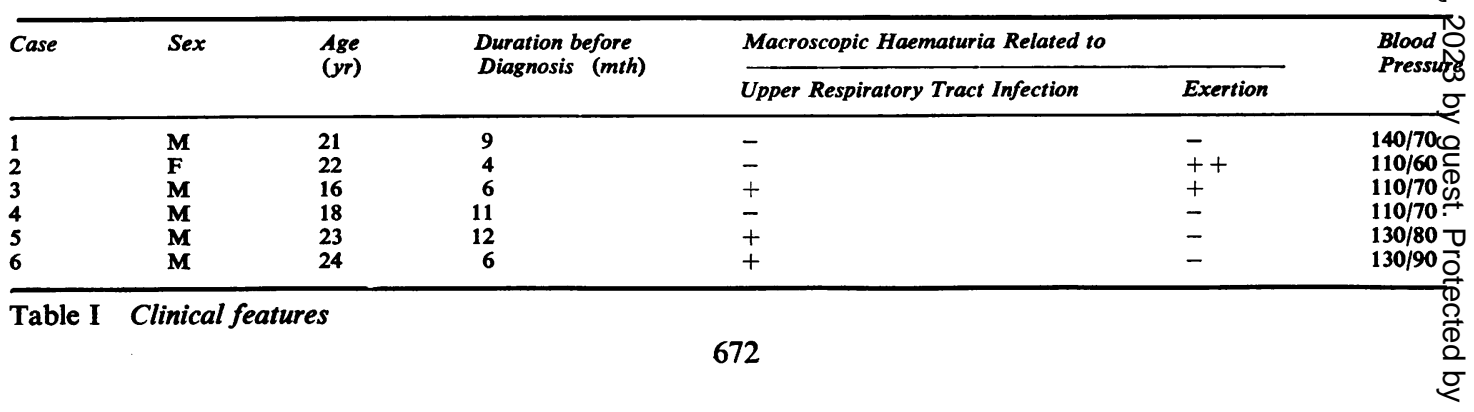




\begin{tabular}{|c|c|c|c|c|c|c|c|c|c|}
\hline \multirow[t]{2}{*}{ Case } & \multirow[t]{2}{*}{$\begin{array}{l}\text { ASO } \\
\text { Titre }\end{array}$} & \multirow[t]{2}{*}{$\begin{array}{l}\text { Proteinuria } \\
\text { (g/24 hours) }\end{array}$} & \multirow{2}{*}{$\begin{array}{l}\text { Serum } \\
\text { Albumin } \\
(\mathrm{g} / 100 \mathrm{ml})\end{array}$} & \multirow{2}{*}{$\begin{array}{l}\text { Blood } \\
\text { Urea } \\
(\mathrm{mg} / 100 \mathrm{ml})\end{array}$} & \multirow{2}{*}{$\begin{array}{l}\text { Creatinine } \\
\text { Clearance } \\
\text { (ml/min) }\end{array}$} & \multicolumn{3}{|c|}{$\begin{array}{l}\text { Immunoglobulins } \\
(\mathrm{mg} / 100 \mathrm{ml})\end{array}$} & \multirow{2}{*}{$\begin{array}{l}\text { Serum } \\
\text { Complement } \\
\text { C3 } \\
(\mathrm{mg} / 100 \mathrm{ml})\end{array}$} \\
\hline & & & & & & $\boldsymbol{I g} G$ & $\operatorname{Ig} A$ & $I g M$ & \\
\hline $\begin{array}{l}1 \\
2 \\
3 \\
4 \\
5 \\
6\end{array}$ & $\begin{array}{l}\text { Normal } \\
\text { Normal } \\
\text { Normal } \\
\text { Normal } \\
\text { Normal } \\
\text { Normal }\end{array}$ & $\begin{array}{l}1 \cdot 2 \\
0 \cdot 2 \\
0 \cdot 2 \\
0 \cdot 4 \\
0 \cdot 4 \\
2 \cdot 5\end{array}$ & $\begin{array}{l}4 \cdot 8 \\
4 \cdot 9 \\
4 \cdot 3 \\
4 \cdot 6 \\
5 \cdot 2 \\
3 \cdot 8\end{array}$ & $\begin{array}{l}25 \\
24 \\
26 \\
34 \\
36 \\
28\end{array}$ & $\begin{array}{r}71 \\
78 \\
92 \\
120 \\
153 \\
117\end{array}$ & $\begin{array}{r}680 \\
1340 \\
1570 \\
1050 \\
1300 \\
980\end{array}$ & $\begin{array}{l}250 \\
188 \\
306 \\
242 \\
218 \\
222\end{array}$ & $\begin{array}{r}70 \\
262 \\
212 \\
126 \\
112 \\
223\end{array}$ & $\begin{array}{l}130 \\
124 \\
142 \\
105 \\
111 \\
167\end{array}$ \\
\hline
\end{tabular}

Table II Laboratory findings

oedema in two cases, leading to a diagnosis of acute nephritis.

Examination revealed no clinical abnormalities and the blood pressure was normal. Creatinine clearance was somewhat reduced in three patients but blood urea levels were normal. The serum immunoglobulins were normal apart from slight rises in IgM levels in two patients. The serum complement (C3) levels were normal.

\section{Renal Biopsy}

\section{METHODS}

All the patients had needle biopsies of the kidney. In each case two cores of renal cortical tissue were obtained. One core was immediately fixed in $4 \%$ methanol-free formaldehyde freshly made up from paraformaldehyde and buffered in sodium cacodylate $\mathrm{pH} \mathrm{7.4.} \mathrm{This} \mathrm{tissue} \mathrm{was} \mathrm{used} \mathrm{for} \mathrm{light} \mathrm{and} \mathrm{electron}$ microscopy. Two blocks containing glomeruli, each $1 \mathrm{~mm}^{3}$, were processed to Epon $812 ; 1 \mu \mathrm{m}$ sections stained with toluidine blue were used to select areas for ultrathin sections and the latter were stained with lead citrate and uranyl acetate before being examined in an Elmiskop 1A electron microscope. The remainder of the formalin-fixed tissue was processed to paraffin and sections stained by $\mathrm{H}$ and $E$, periodic acid-Schiff, methenamine silver, MSB, Congo Red, and Thioflavine $T$. The second core of renal tissue was snap frozen in hexane precooled in a cardice-alcohol bath and then stored at $-70^{\circ} \mathrm{C}$. Immunofluorescence studies were performed on $4 \mu \mathrm{m}$ frozen sections of this tissue. The sections were air dried and treated with fluorescein-labelled antisera (Wellcome Diagnostics FITC-labelled antihuman IgG, IgA, and IgM, and Hoechst antifibrinogen and anti- $\left.\beta_{1} C / \beta_{1} A\right)$. The antisera were tested by immunoelectrophoresis showing that each gave a single line. A blocking test was used on the sections whereby the specific fluorescence was blocked or markedly reduced by treatment with the corresponding unlabelled antiserum. This blocking was not produced by an equivalent dilution of unrelated serum. Negative controls were obtained from other human renal biopsies treated in an identical manner.

\section{Results}

\section{LIGHT MICROSCOPY}

The most prominent glomerular change was segmental mesangial cell proliferation and increase of mesangial argyrophilia (figs 1 and 2). This was minimal in case 1 , more prominent in case 2 , and affected every glomerulus in the remaining four cases resulting in segmental sclerosis in some and global

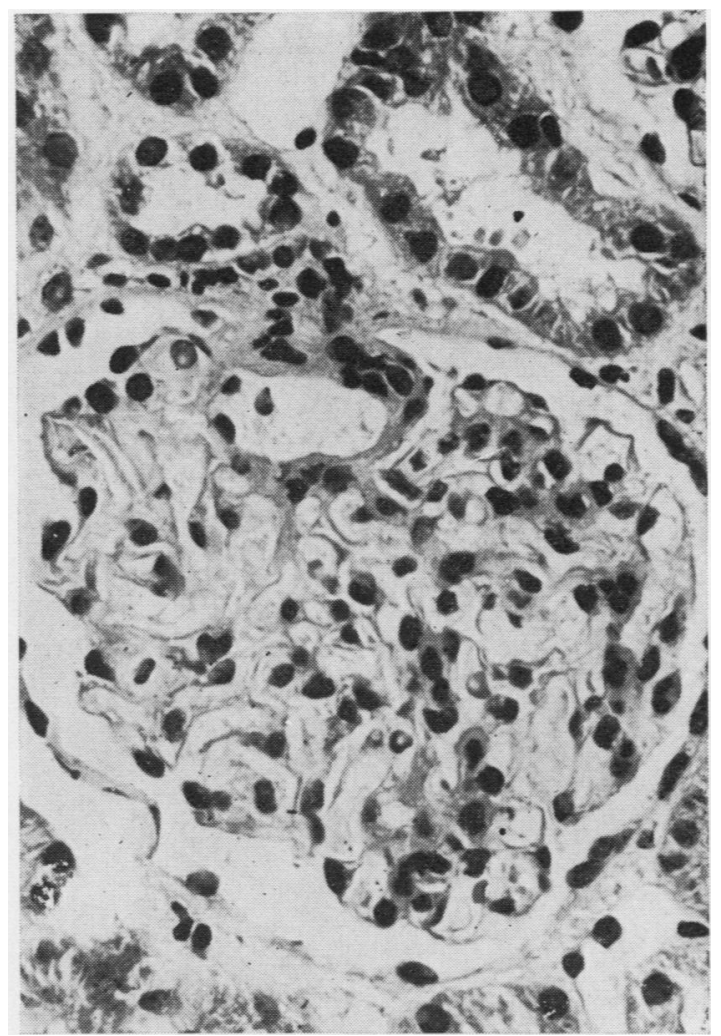

Fig 1 Minimal segmental increase in mesangial cells. Case 3. $H+E . \times 500$. 


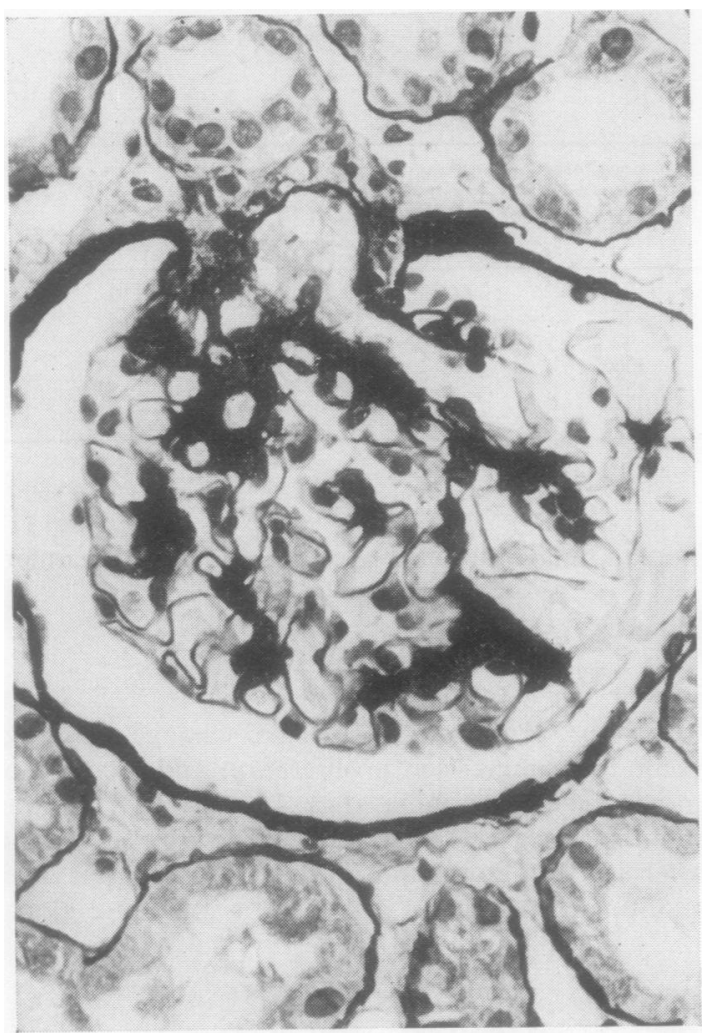

Fig 2 Mesangial argyrophilia but normal thickness of glomerular basement membrane. Case 3. Methenamine silver. $\times 500$.

Fig 3 Electron micrograph showing woolly electron-dense deposits (d) in the mesangium and in the basement membrane of the capillary loop. Case $6 . \times 6250$.

Fig 2

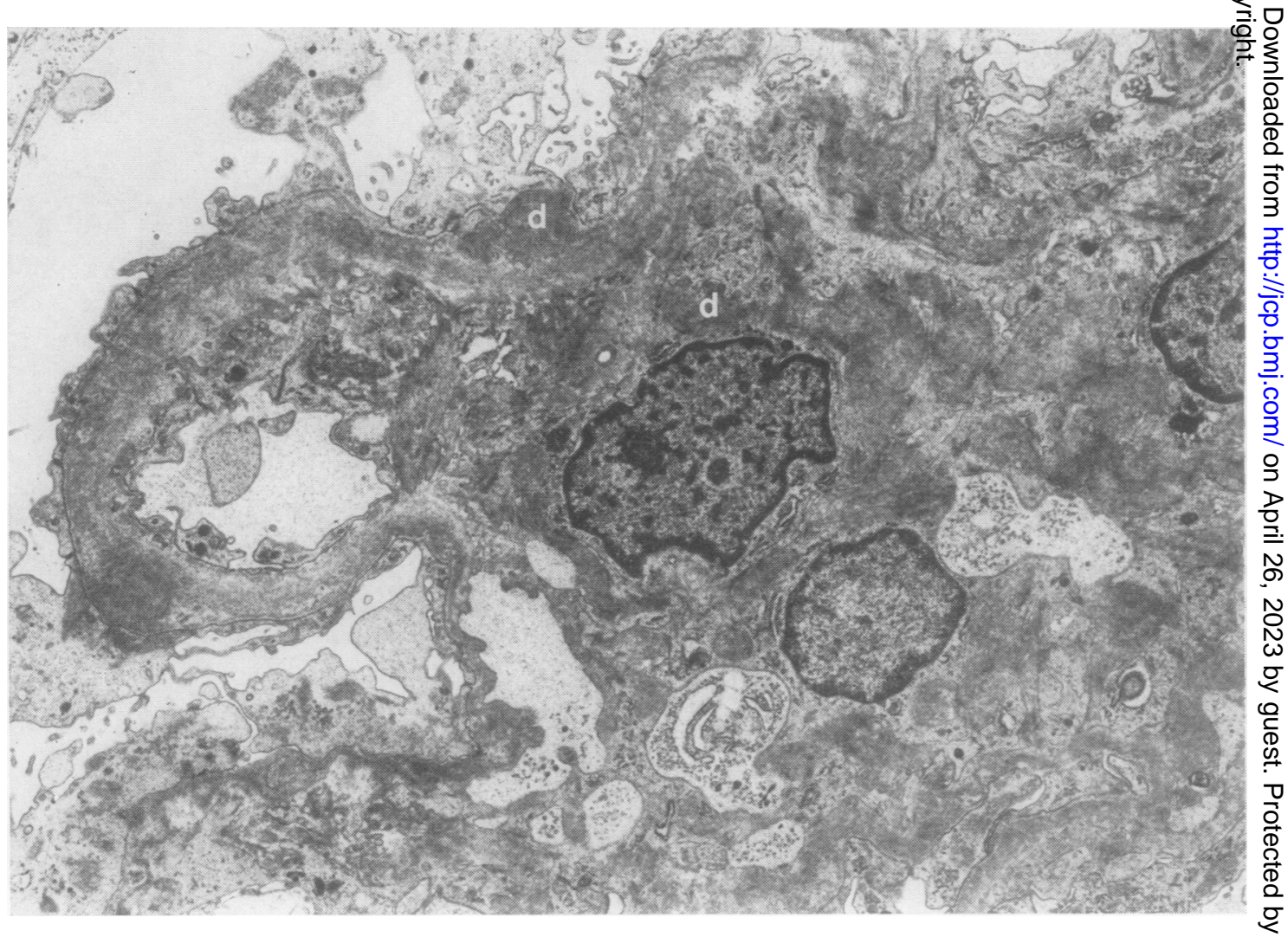

Fig 3 
sclerosis in two glomeruli. Very occasional tuft adhesions and epithelial crescents were present but endothelial cell proliferation was inconspicuous. Peripheral capillary loops in the tufts were mainly patent and thin walled. In each case small foci of two or three tubules showed epithelial atrophy and basement membrane thickening with proportionate increase of interstitial connective tissue. Several tubules in each biopsy contained red blood cells. Extraglomerular blood vessels looked normal.

\section{ELECTRON MICROSCOPY}

The mesangium was prominent in every case. There were more mesangial cells than normal and there was an increase in the amount of matrix. Areas of increased density in the mesangial matrix (interpreted as 'deposits') were present in five of the six cases (fig 3). The basement membrane of the capillary loops looked normal in most cases though in one case there was an isolated subendothelial deposit and in another occasional deposits were seen within the basement membrane (fig 3). Glomerular endothelial and epithelial cell changes were un-

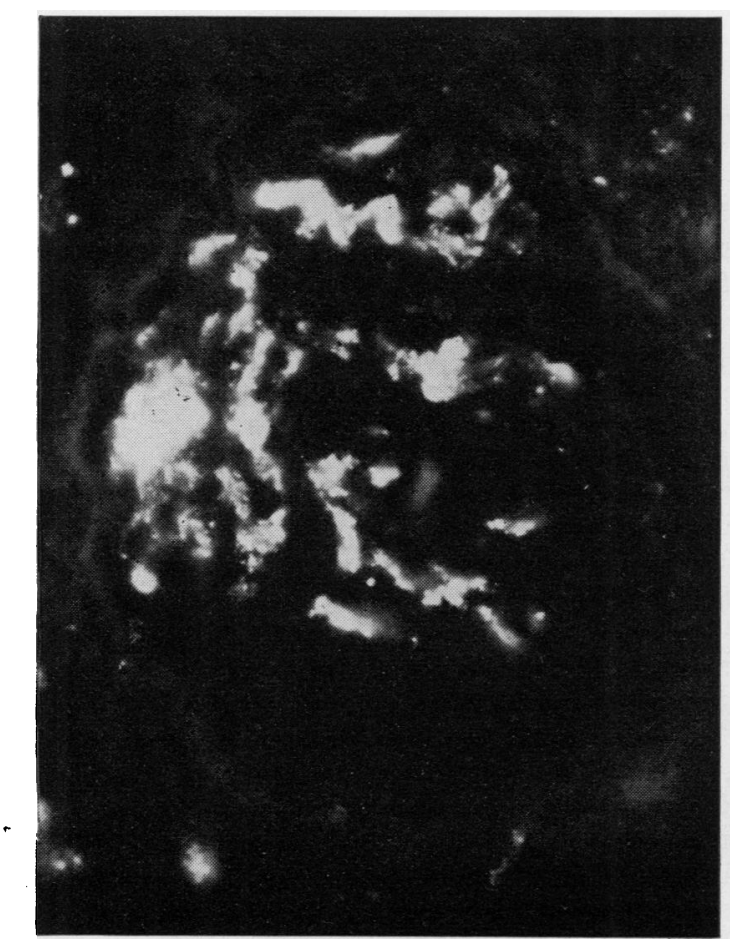

Fig 4 Glomerular fluorescence using FITC-labelled antihuman IgA. The glomerulus is sectioned close to its hilum and the arborescent pattern of mesangial fluorescence is seen. Case 5. $\times 650$. remarkable. Electron-dense deposits were seen in the wall of an arteriole in one case.

\section{IMMUNOFLUORESCENCE}

The glomerular immunofluorescence findings are summarized in table III. The intensity and extent of the glomerular staining were variable but it was always mesangial in distribution. An equatorial section through the hilum of a glomerulus revealed an arborescent pattern (fig 4) but eccentric sections

\begin{tabular}{llllll}
\hline Case No. & IgG & IgM & IgA & Fibrin & C3 \\
\hline $\mathbf{1}$ & - & + & + & - & - \\
2 & - & + & ++ & - & + \\
3 & + & - & ++ & - & ++ \\
$\mathbf{4}$ & - & \pm & ++ & + & + \\
$\mathbf{5}$ & \pm & \pm & ++ & + & + \\
$\mathbf{6}$ & - & + & ++ & \pm & + \\
\hline
\end{tabular}

Table III Summary of glomerular immunofluorescence findings ${ }^{1}$

${ }^{1}$ Fluorescence findings recorded on arbitrary scale. - negative, \pm doubtful, + weak positive, ++ moderate intensity, +++ very heavy.

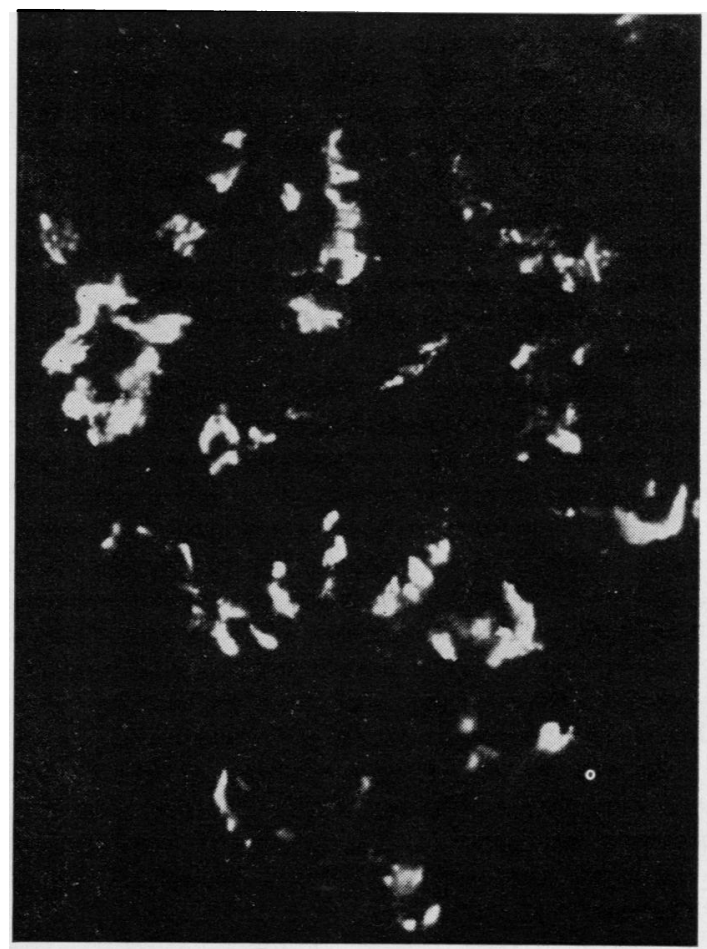

Fig 5 Glomerular fluorescence using FITC-labelled antihuman $\operatorname{IgA}$. The glomerulus is not cut through its hilum and the mesangial IgA deposits are apparently discrete. Case $5 . \times 700$. 
showed mesangial fluorescence in which the deposits appeared discrete (fig 5). Staining for complement was seen in the walls of arterioles in two cases.

\section{Discussion}

IgA deposits are often prominent in the glomerular lesions of disseminated lupus erythematosus and Henoch-Schönlein purpura but are not associated with acute poststreptococcal proliferative glomerulonephritis, membranous glomerulonephritis, or foot process disease and are not often found in most forms of chronic proliferative glomerulonephritis (Berger, 1969; Bariety and Druet, 1971). In the form of glomerulonephritis described by Berger, mesangial IgA deposits are the predominant feature on immunofiuorescence but $\operatorname{IgG}$ and $\mathrm{C} 3\left(\beta_{1} \mathrm{C} / \beta_{1} \mathrm{~A}\right)$ may also be found. Berger (1969) found these other components in almost all of his cases though they were less easily demonstrated than IgA. MorelMaroger et al (1972) also found similar deposits of IgG and C3 in all their cases but Bariety and Druet (1971) found IgG in only $65 \%$ and C3 in $74 \%$ in patients with this disease. In our patients we detected IgG in only one and $\mathrm{C} 3$ in four of the six cases.

If light microscopy alone is used then renal biopsies from patients with Berger's nephropathy may be mistakenly classified as normal, others may be diagnosed as focal or diffuse glomerulonephritis or as unspecified chronic nephritis (Berger, 1969). The variability of the light microscope picture contrasts with the constancy of immunofluorescence findings where the mesangial IgA deposition almost always affects all glomeruli and all segments of those glomeruli.

In some patients with Berger's nephropathy the episodes of macroscopic haematuria are related to sore throats or to upper respiratory tract infections although no causal organism has been consistently identified. Attempts to implicate streptococci specifically have not been successful, for few patients have raised ASO titres, the organism is rarely isolated from these patients, and mesangial IgA deposition is not a feature of acute poststreptococcal glomerulonephritis. Berger suggested that the tonsils being rich in IgA-secreting plasma cells may be significant in the association of exacerbations of this disease with sore throats (Berger, 1969). Exercise may be a precipitating factor of the attacks of macroscopic haematuria and was a prominent feature of two of our cases.

Apart from haematuria, patients with this condition usually have slight proteinuria. Renal function is usually well preserved at presentation but more information is needed before the natural history of the disease can be determined. It has been claimed that up to $19 \%$ may have renal insufficiency and $32 \%$ hypertension (Druet et al, 1970) but in mose cases the disease seems to progress little over many years.

The relationship of this disease to 'benign haema-들 turia of childhood' is not certain but there are many similarities. Reports of the renal pathology of the childhood condition show discrepancies in theo number of cases which showed abnormalities depending on the amount of mesangial or otherfocal proliferation which the individual pathologise accepts as being 'within normal limits' (Ayoub anc Vernier, 1965; Bodian et al, 1965; Glasgow et al 1970; Chen et al, 1972). It is important to stress tha용 without immunofluorescence techniques, mesangiais IgA glomerulonephritis cannot be diagnosedio Lannigan and Insley (1965) describe the light andig ultrastructural appearances in five such childhood cases. Their description of focal changes showing "variable cellular proliferation, mainly endothelial and axial' and 'increase in basement membrane-likes material in axial zone' is much like the mesangia changes noted in this report. The benign reputation of the childhood disease may not be entirely justified, for although the proteinuria and haematuria occur. over many years without impairment of reßa function it is not known whether these children haje a higher incidence of renal disease in later (Edelman and Barnett, 1971).

Mesangial immunoglobulin deposition withou basement membrane involvement has been shown tő occur in immune-complex disease (Germuth Senterfit, and Dreesman, 1972). This was produced in rabbits by repeated injection of small doses of bovine serum albumin: one group of animals responded with intermediate levels of antibody? production which resulted in immune complexes. larger than those penetrating the glomerular base? ment membrane but smaller than those taken up by the reticuloendothelial system. The intermediate size $h$. complexes were deposited in the mesangium where focal cellular proliferation and electron-dense deposits were seen-similar morphological findings to this human disease. However, IgG was the immuno $\frac{7}{0}$ globulin involved in the animals studied.

Though much has been discovered about $\operatorname{IgA}$ irf secretions, its role in the circulation is unknown Until recently it was thought to be unassociated with complement activation but Götze and Müller $-\omega$ Eberhard (1971) have shown that aggregated IgA can activate complement via the alternate pathwayo presenting a possible mechanism for the association of IgA with complement in this disease. Observations on case 4 in the present series suggested activation of the alternate pathway for complement, and further studies are in progress. 
We are grateful to Mr A. E. Clark, Mr D. J. Turvey, and $\mathrm{Mr} \mathrm{V}$. Clark for technical assistance, and to Mrs M. R. Rasbridge and Dr G. L. Scott for the serum immunoglobulin and complement measurements and for immunoelectrophoretic testing of the fluorescein-labelled conjugate.

\section{References}

Arneil, G. C., Lam, C. N., McDonald, A. M., and McDonald, M. (1969). Recurrent haematuria in 17 children. Brit. med. J., 2, 233-235.

Ayoub, E. M., and Vernier, R. L. (1965). Benign recurrent haematuria. Amer. J. Dis. Child., 109, 217-223.

Bariety, J., and Druet, P. (1971). Résultats de l'immunohistochemie de 589 biopsies Rénales (Transplantes exclus). Ann. Méd. interne., 122, 63-69.

Berger, J., Neveu, T., Morel-Maroger, L., and Antoine, B. (1967). Applications de l'immunofluorescence en néphrologie. Actualitiés néphrol. Hôp. Necker, 172-173.

Berger, J., and Hinglais, N. (1968). Les dépôts intercapillaircs d'IgAIgG. J. Urol. Nephrol., 74, 694-695.

Berger, J. (1969). IgA glomerular deposits in renal disease. Transplant. Proc., 1, 939-944.

Bodian, M., Black, J. A., Kobayashi, N., Lake, B. D., and Schuler, S. E. (1965). Recurrent haematuria in childhood. Quart. J. Med., n.s. 34, 359-382.
Burkholder, G. V., Dotin, L. N., Thomason, W. B., and Beach, P. D. (1969). Unexplained hematuria. J. Amer. med. Ass., 210, 1729-1733.

Chen, B. T. M., Ooi, B. S., Tan, K. K., and Khoo, O. T. (1972). Causes of recurrent haematuria. Quart. J. Med., n.s, 41, 141-148.

Druet, P., Bariety, J., Bernard, D., and Lagrue, G. (1970). Les glomérulopathies, primitives a dépôts mésangiaux. d'IgA et d'IgG. Presse méd., 78, 583-587.

Edelman, C. M., Jr., and Barnett, H. L. (1971). In Diseases of the Kidney, edited by M. B. Strauss and L. G. Welt, 2nd ed., vol. 2, p. 1369. Little, Brown, Boston.

Germuth, F. G., Jr., Senterfit, L. B., and Dreesman, G. R. (1972). Immune complex disease. $\mathrm{V}$. The nature of the circulating complexes associated with glomerular alterations in the chronic BSH-rabbit system. Johns Hopk. Hosp. med. J., 130, 344-357.

Götze, O., and Müller-Eberhard, H. J. (1971). The C3 activator system: an alternate pathway of complement activation. J. exp. Med., 134, 90-1085.

Glasgow, E. F., Moncrieff, M. W., and White, R. H. R. (1970). Symptomless haematuria in childhood. Brit. med. J., 2, 687-692.

Hendler, E. D., Kashgarian, M., and Hayslett, J. P. (1972). Clinicopathological correlations of primary haematuria. Lancet, 1, 458-463.

Lannigan, R., and Insley, J. (1965). Light and electron microscope appearances in renal biopsy material from cases of recurrent haematuria in children. J. clin. Path. 18, 178-187.

Morel-Maroger, L., Leathem, A., and Richet, G. (1972). Glomerular abnormalities in non-systemic disease. Amer. J. Med., 53, 107. 184. 